\title{
The bio-financialization of Irish Water: New advances in the neoliberalization of vital services
}

\author{
Patrick Bresnihan \\ Maynooth University Sociology, NIRSA, Maynooth, Kildare, Ireland
}

\section{A R T I C L E I N F O}

\section{Article history:}

Received 30 May 2015

Received in revised form

19 November 2015

Accepted 20 November 2015

Available online 20 December 2015

\section{Keywords:}

Bio-financialization

Water

Neoliberalism

\begin{abstract}
A B S T R A C T
This paper examines ongoing efforts to establish a new semi-state, commercial water utility in Ireland. The new utility, Irish Water, marks a significant break with the previous public service model of water and wastewater provision both in terms of how it is financed and how it is governed. The Irish government asserts that these reforms are a necessary response to the twin challenges of an aging water infrastructure and the fiscal challenges of the Irish state. In this paper I outline how the convergence of these environmental and financial demands are provoking new advances in the neoliberalization of water services. I argue that the organizational and technical composition of Irish Water suggests the extension of both financial logics and highly technical environmental metrics into the water sector, what I call the process of bio-financialization.
\end{abstract}

(c) 2015 Elsevier Ltd. All rights reserved.
In this light, we might hope that leading governments will help finance capital realize its profound potential to remake the arteries through which capital flows and that are the lifeblood of the biological and social reproduction of most of contemporary humanity (Castree and Christophers, 2015: 8).

\section{Introduction}

On the 2nd February 2015, live on the national evening news, Ireland's Minster for the Environment, Alan Kelly, made it clear why household water charges were being introduced and why there was a need to establish a new water utility called Irish Water. Up until this point the government had been keen to stress that water charges were both necessary to incentivize water conservation and to finance critical upgrades of an aging water infrastructure. Alan Kelly went a step further, however. He admitted that the new water utility was established not only to charge for water use but also to take the financing of water services off the general exchequer balance sheet: as an independent, semi-state company, Irish Water would be able to borrow directly from international credit markets.

While this was a significant admission it has not received much attention from the media, the opposition parties, or even the considerable, grassroots movement resisting the introduction of

E-mail address: bresnip@tcd.ie. water charges. Perhaps unsurprisingly, the main points of contention have been the regressive nature of the water charges coming after five years of government austerity policies as well as the corporate nature of the new utility - controversies over paybonuses, high salaries for the executives and the general unaccountability that surrounds the new utility have all been targeted by opponents. The movement against the water charges has also connected with water justice movements around the world, adopting familiar slogans that claim water as a human right and oppose the privatization and commodification of water. This discourse becomes somewhat ambiguous in the case of Irish Water, which is a state-owned and thus technically public utility. Getting around this, campaigners have argued that the new model of water provision is just the 'obvious' first step towards full privatization and thus must be resisted.

While these arguments are valid and important they can tend to be picked up uncritically, assuming that what we are experiencing is neoliberal 'business as usual': market-based institutions replacing what should be a public service. What can be glossed over in this analysis are the specific forms that neoliberal rationalities take as the challenges of failing infrastructures and the fiscal crises of the nation-state unfold within the rapidly changing contexts of the global economy, ecological uncertainty and supra-national regulatory frameworks. In other words, Irish Water does not emerge as a well-formed neoliberal project implemented by canny policymakers with no regard for the public good. It is an experiment that must be placed within a longer process of failed water service 
models and emergent financial and environmental demands (and possibilities). It is this convergence that opens up new relationships between the state and the market, the public and the private. This isn't to suggest that the current re-organization of water services in Ireland is inevitable but it avoids interpreting it as just another example of neoliberal ideology being imposed on the population by governing elites.

Research on the changing political economy and political ecology of water provision has been one of the richest sources for tracing and understanding neoliberal transformations in the provision of vital services historically associated with the state (Bakker 2003a,b, 2005; Budds \& McGranahan; 2003; Kaika, 2003; Swyngedouw, 1997). From the 'heyday' of water privatization in the 1990s we have witnessed dramatic changes across different parts of the globe as 'better' solutions are sought for the chronic problems of water shortages and lack of investment. Scholars have documented the changing accumulation strategies of private companies involved in different aspects of water services, from long-term and high-risk agreements (full-ownership or concession), to shorter operational contracts, to new interventions in the water cycle such as desalination and environmental management services (see Bakker, 2013; Hall and Lobina, 2010). As the role of the private sector in water services has changed so too has the role of the state: from public-private partnerships that re-distribute the costs and risks associated with capital infrastructure projects to new forms of 'public' water management, including the turn towards re-municipalization (Pigeon et al. 2012; Schwartz 2008; Van Rooyen and Hall, 2007). While some argue that this is a positive 'return' of the state to the public management of essential services (Ramesh and Araral 2010), others point to the re-formulation of neoliberal market practices and logics within state-owned utilities, effectively challenging any remnant of the public-private binary that has been one of the hallmarks of 'anti-neoliberal' struggles (McDonald, 2014; Smith 2004, 2006). In other words: while the 'return' of the state may reflect the failure of previous arrangements, these failures do not mean the end of neoliberalism. Indeed, it is the capacity to respond to such failures that characterizes neoliberal governance, provoking new configurations of the state, market, society and non-human natures. In this paper, I examine how new fiscal and environmental demands on the Irish water sector are generating new financial and technical fixes. I describe this as the bio-financialization of the water sector because of the convergence of two dynamics that are rarely analyzed together in the literature: financialization and ecological modernization. ${ }^{1}$

While large amounts of finance capital have always been involved in the production of core, physical infrastructures the changing and growing role of the finance sector in the shaping of infrastructure provision indicates that something different is at stake today (Epstein, 2005; Lapavitsas, 2009). In the case of Irish

\footnotetext{
1 In their article, "The Unintended consequences of ecological modernization: debt-induced reconfiguration of the water cycle in Barcelona" (2013), March and Saurí make an important connection between ecological modernization, financialization and the neoliberalization of water services. They show how compliance with the European Water Directives resulted in considerable costs and debts being accrued by the Catalan Water Agency during the 2000s. When combined with European fiscal restrictions introduced through the European Stability Pact (1992), this situation became unmanageable even before the 2008 financial crisis. The conclusion of this debt-induced reconfiguration of the Catalan water system was the almost 'inevitable' privatization of the public raw water supplier (ATLL). However, while the connections March and Saurí make between ecological modernization, financialization and neoliberalism are important they don't suggest, as I am in this paper, that the connections extend to a growing emphasis on the measurement and demonstration of environmental and financial performance across the water system. This tendency has far-reaching consequences in terms of the organizational and technical composition of the water sector.
}

Water, the goal of accessing capital on financial markets (most likely through the issuing of bonds) first requires securing a regular stream of revenue (from household water charges) and then demonstrating the financial efficiency and regulatory compliance of the utility to potential investors. The attractiveness of investments in water infrastructure, particularly for pension funds, reflects the monopoly nature of water service provision, ensuring captive income streams with known rates over fixed time periods (Courtois, 2013). At one level this means that private (financial) actors can operate at more of a distance from the daily operations of the water system itself while still profiting from the provision of water services through new forms of financial rent. At another level the apparent distance between the 'real' operations of the water utility and new sources of finance ignores the significant ways in which access to external private finance is shaping the organization and management of water systems 'on the ground'. In order to be assured that an infrastructure project is worth investing in an investor needs to be confident that the project is low-risk and will return a good yield on their investment as compared to other potential investments. This means that the infrastructure project itself must be translated into the legible terms of financial investors - in terms of efficiency, strong and transparent management and regulatory compliance (EC Harris 2013; OECD, 2010). ${ }^{2}$ This has led scholars of financialization to point to the important organizational and technical transformations that are required to transform an activity or resource into a financial asset to begin with (Christopherson et al. 2013; Leyshon and Thrift 2007). ${ }^{3}$ As Christopherson et al. write,

Finance has ceased simply to assist the running and operation of the real economy of goods and services, but rather has come to dominate, even displace, the latter. Financial rationales and practices have re-shaped performance metrics not just for enterprises across all sectors of the economy but also throughout the public sector and utilities, including health and social services, thereby affecting the social well-being and welfare of households (2013: 351-352; my italics).

What is important to understand in this regard is that the financialization of water infrastructures is not the same as the financialization of water resources, as may happen in the way oil or land has been financialized through futures contracts. Rather it is the entire network of services and assets involved in the delivery of water and wastewater treatment that is becoming embroiled within the contemporary financial environment (Hall and Lobina 2010; Loftus \& March 2015; March and Purcell, 2014).

Ecological modernization has a long history as both an academic concept and a policy framework (Beck, 1994; Warner, 2010; Mol and Spaargen 2000). Contradicting the gloomy, neo-Malthusian prognoses of environmental and development economists in the 1960s and 1970s, for example, post-industrial visions of economic growth posited that the potential for social and economic development need not be restrained by natural limits (Cooper 2008).

\footnotetext{
2 As the OECD makes clear, "[i]nfrastructure financing is often seen to be risky, largely as a result of regulatory risk. Governments therefore also need to find ways to make infrastructure investment attractive by mitigating these risks without removing incentives to manage risk" (OECD 71; my italics).

${ }^{3}$ While much of the work on the financialization of infrastructure examines changing ownership patterns in the water sector (Helm and Tindall, 2009) and the financial engineering that enables various intermediaries to profit from revenue streams associated with tolls or pay-per-use services (Allen and Pryke, 2013; Ashton et al. 2012), I am mostly interested in the process through which an infrastructure becomes a financial asset to begin with; the transformations that are necessary to turn something like a water system into a financial asset.
} 
This vision does not mean, however, that we ignore the negative environmental 'externalities' of industrial production, but rather advance beyond this mode of production by properly accounting for non-human nature within new economic, social and ecological configurations. At its heart, ecological modernization is driven by the belief that economic growth is not just compatible with ecological sustainability but inextricably connected to it through technological innovation and market incentives. In terms of the ecological modernization of the hydro-social cycle, this means designing and implementing appropriate policies, techniques and technologies that enable more efficient water-use (and increasingly energy-use) from the household to the national utility. While this takes the form of new regulations and incentive-based instruments (user-pays principle), it also demands new ways of measuring water (and energy) use, water quality and the overall performance of the infrastructure which harnesses, processes and distributes water and wastewater. This is opening up new, profitable opportunities for ICT companies in the area of environmental services and resource management, as well as changing how water systems are being managed at a domestic and national scale. In this paper I explore how this emphasis on measuring and regulating the environmental performance of the water system dovetails with the need to demonstrate the financial performance of the water utility for potential investors. This process takes the form of new organizational and technical innovations in the Irish water sector that are transforming how water and the extensive infrastructure that accompanies it are being valued and developed.

The paper proceeds in three steps. First, I briefly describe the double crises facing the Irish state. On one hand, there is a looming hydro-ecological crisis that is closely connected to an ageing and failing water infrastructure that can no longer cater to the changing demands of Irish society or the new risks and regulatory requirements associated with environmental change. On the other hand, since 2008 the Irish state has been in the midst of an unprecedented fiscal crisis that has put tremendous pressure on its ability to provide basic public services, such as water supply and treatment. In part two I describe the new semi-state utility, Irish Water, which has been tasked with responding to this double crisis. I show how the imperative to access external finance converges with new environmental demands to 'modernize' the water infrastructure, resulting in the organizational and technical composition of the new utility. Finally, I conclude by emphasizing the need to better examine the convergence of financial logics and ecological modernization; the growing centrality of new technologies and techniques of measurement in shaping core infrastructures; and the importance of such analyses in debates and struggles for more just, participatory and inclusive hydro-social futures.

\section{The bio-financial crisis of the Irish Water system}

\subsection{Hydro-social crisis}

The Irish water system is in trouble. To begin with an estimated 23,000 people are currently on Boil Water Notices, ${ }^{4}$ meaning their water is not fit for drinking due to the risk of microbiological contamination (Doris et al. 2013). In some areas, people have been under this notice for several years and do not face the prospect of relief until 2021 at the earliest. The Environmental Protection Agency (EPA) has identified that wastewater treatment is not at the required standard in 38 of the larger urban areas and $30 \%$ of water

\footnotetext{
${ }^{4}$ A boil-water advisory or boil-water order is a public health directive given by government or health authorities to consumers when a community's drinking water is, or could be, contaminated by pathogens.
}

treatment plants are considered to be "at risk" of failure in terms of Irish and European quality parameters. As a result of Ireland's failure to meet the requirements of the EU Urban Waste Water Treatment Directive in respect of 71 areas in 2011 the European Commission has initiated an Infringement Case against the state.

As well as problems with the treatment of water and wastewater, Ireland also faces problems with water capacity, particularly for the growing demand in the capital. Overall, $37 \%$ of the identified 'Gateway and Hub' settlements throughout the country lack capacity to cater for planned populations in 2016 in terms of water supply and wastewater infrastructure (PWC 2011). In November 2013, water supply throughout Dublin was cut for several consecutive nights because of water shortages, including to commercial properties - leading to claims by some media commentators that Ireland was like a 'third world country'. In March 2015, Irish Water published a 'Need Report' for the proposed Eastern and Midlands Region Water Supply Project (WSP) that identified projected demand for water in Dublin to increase by over $50 \%$ by 2050 . On its website it stated that "[i]mprovements to and maintenance of the existing water supply system, will not meet that level of need. A new source must be developed and utilized".

Existing water shortages have also been connected to reduced rainfall (related to climate change ${ }^{5}$ ) and growing demand on water resources from the urban population. Besides potential reductions in rainfall, the other water-related risk associated with climate change is the prospect of heavy and severe rainfall resulting in flooding and the escape of raw sewage out of the wastewater system. Even leaving aside these unprecedented and unpredictable risks and pressures from demographic and environmental change, continuing reliance on a 19th century water infrastructure that has suffered from chronic under-investment currently results in the loss of $40 \%$ of water in the system through leakage (PWC 2011). Recently the detection of lead in household drinking water has also resulted in temporary boil water notices. This lead is dissolved into the water supply from pipes that were laid pre-1960. The public water system in Ireland consists of $60,000 \mathrm{~km}$ of piping (most of which is underground) not including the connections between the mains pipes and household taps. To fix or replace this piping is a colossal task that clearly requires considerable financial and technical resources. While the Irish government invested almost $€ 5.2$ billion in the water sector between 2000 and 2009 most of this went towards filling the substantial compliance gap under the European Urban Waste Water Treatment Directive. Currently operating costs of water and wastewater services are approximately $€ 1.2$ billion per annum, of which around $€ 1$ billion was historically provided by the Government through taxation, with other sources, including non-domestic water charges, contributing just over $€ 200 \mathrm{~m}$. An estimated additional $€ 20$ billion investment in the water system up to 2030, is thought to be necessary (PWC 2011).

While not receiving much attention in either the literature on water provision in Europe or in the debates surrounding the setting up of a new utility in Ireland, the role of European regulatory frameworks in shaping the role, governance structures and, effectively, financing of water utilities has been considerable. In one sense, European regulations around water use and management have been progressive. Efforts to account for the negative effects of pollution, urban expansion and the inefficient use of water

\footnotetext{
5 Successive EPA reports $(2009,2013)$ on the state of knowledge on climate change impacts for Ireland, identifies that changing patterns of precipitation will impact on water services provision and on levels of pollution and contamination, with significantly wetter winters particularly in the west, and drier summers particularly in the south east and storm occurrences of a greater intensity.
} 
resources have resulted in the Urban Wastewater Treatment Directive (1992), the Drinking Water Directive (1998) and, most significantly, the Water Framework Directive (2000). These directives not only place a financial burden on member states but also determine the scale and goals of water management (Kaika, 2003; Petersen et al., 2009; Thiel, 2009). Rather than managing water resources according to social or political boundaries (municipality, region etc.), the Water Frameworks Directive (WFD), for example, calls for an integrated, river basin approach that more closely reflects the ecological dimensions of the water cycle. This in turn requires carrying out holistic baseline data analysis of river basins, including estimating the social, ecological and economic costs of different measures based on future population and development scenarios.

Water management within the EU is no longer just about maintaining existing infrastructures, but of implementing new ways of monitoring, assessing and managing more and more aspects of the water system in response to projected future developments and risks (CEC, 2012). In November 2011, the European Commission wrote to Ireland and nine other member states warning that they had incorrectly interpreted the concept of 'water services' (Whittaker, 2012). The Commission considers 'water services' to be a much broader concept than just the supply of drinking water and treatment of wastewater for humans. Understood as part of Europe's 'natural capital', water resources provide many functions within the economy and wider ecology that need to be accounted for (European Environment Agency, 2015). For example, water services includes the cost of water abstraction for cooling industrial installations and agricultural irrigation, the impoundment or storage of surface waters for navigation purposes, flood protection, hydro power production, as well as drilling for agricultural, industrial or private consumption. According to the Commission, the exclusion of these activities from the definition of water services, and the failure to properly account for and value these services, is a breach of the provisions of Article 9 of the Water Framework Directive. This brings with it technological requirements (data monitoring and analysis, environmental services, more efficient treatment plants) and reforms in water governance so that state institutions are capable of adapting to these new demands. All of this costs money: full compliance with the Water Framework Directive has not been properly costed but is likely to run to several billion euro over the period to 2027 (PWC 2011).

\subsection{Financial crisis}

In 2007-8, Ireland's economic 'miracle' ended when the property-led bubble burst in the wake of the international financial collapse. The banks which had been key facilitators of the speculative real-estate economy through high value, risky lending, were given a blanket guarantee by the government in 2008 worth $€ 64$ billion. State finances were crippled by this massive transfer of public money into the private banking system but also by the sharp drop in tax revenues from an economy that had been so reliant on construction and property sales. As the structural weaknesses of the Irish economy soon became clear, the cost of borrowing on international markets became prohibitive and the Irish government was faced with no options in terms of filling the financing gap. In December 2010, Ireland received $€ 85$ billion in bailout funds from the European Commission, the European Central Bank and the IMF. As has become well known these funds were tied to certain fiscal conditions and structural reform promises laid out in a new Program of Financial Support for Government that was to last until 2014. This program required a $€ 10$ billion reduction in annual government spending and a $€ 5$ billion increase in annual tax receipts. The goal was to bring Ireland back in line with European budgetary targets laid out in the Stability Pact Agreement of 1992.

The Troika Program also came with specific conditions related to the financing of water services. Ireland was already the only member state not to charge for domestic water use. ${ }^{6}$ With the bail out restrictions on government spending and the high costs required to bring the water system into line with European water directives it was clear that the Irish state could no longer defend this situation. The Program of Financial Support for Ireland agreed between the Government and the EU/IMF required that by the end of 2011 the Government had to have undertaken an independent assessment of the transfer of responsibility for water services provision from the local authorities to a new water utility. In the Program for National Recovery, 2011-2016, the Government signaled its intention to create a new State company to take over water and wastewater functions from the 34 existing local authorities. While Ireland is still in the early stages of this transition it is important to understand the reasoning behind the decisions that have been taken so far. Faced with an aging, inadequate water infrastructure and demanding European water directives at a time when there are fiscal limitations on what the government can borrow and spend, the goal of accessing new sources of finance in order to modernize the water system has become primary. As I will show in the next section this is not simply a case of raising new revenue through water charges - which would never be enough but of establishing a new, independent semi-state water utility that will be able to borrow directly from global financial markets. At the same time, the need to attract such investment is bound up with the ability of the new utility to demonstrate that it is compliant with environmental regulations and efficient across all aspects of its operations, including in the management of the underlying water and infrastructure assets.

\section{The bio-financial fix: Irish Water}

\subsection{Off-balance sheet financing: Re-organizing the Irish Water sector}

The relationship between finance capital and the development of modern water infrastructures is well known: to harness, process, distribute and move water and wastewater requires considerable amounts of money (Budds and McGranahan, 2003; Swyngedouw, 2006). In the twentieth century, the expansion of the industrial water systems was inextricably tied to the availability of capital, whether in the form of surplus capital being re-directed into speculative, interest-bearing investments (Swyngedouw, 1997), or mediated through financial institutions such as the World Bank (Bakker, 2013). Indeed, one of the primary justifications for the increased role of the private sector in the provision of water services in the 1990s and 2000s was their assumed ability to access finance. As early as 2003 this assumption was recognized to be flawed by the World Bank in its response to the Camdessus/World

\footnotetext{
${ }^{6}$ When the EU member states, including Ireland, adopted the Water Framework Directive in 2000, Ireland secured an exemption or 'carve-out', upon which successive Governments have relied ever since in order to avoid charging domestic consumers for water services. Under article 9(1) of the Water Framework Directive, member states are required to "take account of the principle of recovery of the costs of water services, including environmental and resource costs, having regard to the economic analysis conducted according to Annex III of the directive and in accordance in particular with the polluter pays principle." Article 9(4) of the Directive includes the 'carve out', which has been described as the 'Irish derogation' even though it is not limited in its effect to Ireland. It provides that a member state will not be in breach of the Directive if it decides - in accordance with established practices - not to apply the provisions relating to cost recovery "where this does not compromise the purposes and the achievement of the objectives of this Directive."
} 
Panel on Financing Water Infrastructure: private sector finance had provided less than $10 \%$ of necessary capital, and the declining trend in private sector investment was likely to continue (Camdessus and Winpenny, 2003). The limited amounts of private investment in infrastructure projects became more pronounced in the immediate aftermath of the 2008 financial crisis (Fine, 2009; Hall, 2009).

The failure of the private sector to invest sufficiently in infrastructure has opened the door for the state to fulfill that function, not through general taxation as was the case in the past, but through new forms of financial engineering that will enable the raising of 'market-based repayable finance' (OECD, 2010; Turner, 2014). ${ }^{7}$ The question is how can the financial needs of municipal and national governments be brought together with the interests of financial investors looking for new activities and assets to invest in ${ }^{8}$ This new field of infrastructure financing now occupies many pages in the reports and commentaries of policy-makers and financial experts seeking to bridge the financing gap required to improve and expand core infrastructure and services (Clark et al. 2012; EC Harris 2013; Inderst, 2009; OECD, 2014; Thompson, 2013).

In the shift towards market-based repayable finance the question of private or public ownership takes on yet another twist in the story of neoliberal transformations. There is no need for a publicly owned utility to be privatized before it becomes a target for financial investors. ${ }^{9}$ As I will show in the case of Irish Water, the Irish government is the principal actor involved in transforming a public service model of water provision into a commercial semistate company that can attract the interests of institutional investors. This is corroborated by OECD reports:

Finally, the boundaries between the public and private sectors have been blurred and the controversial nature of the debate on PSP has abated somewhat, with more dialogue going on at sector level and the recognition that a number of reforms are required regardless of ownership. In that context, market-based finance can potentially make a significant contribution to bridging the financing gap in the water sector, for private and public water service providers alike" (OECD, 2010: 22).

As Minister Alan Kelly made clear, the main reason for establishing Irish Water was to open up new ways of financing the capital-intensive infrastructure upgrades required by Ireland's water system. Faced with the fiscal constraints on government expenditure and borrowing the first step involved in this process is to get the cost of water services off the general balance-sheet. This

\footnotetext{
${ }^{7}$ It is important to distinguish between sources of funding for infrastructure projects and the financing of such projects. As O'Brien and Pike outline, "[t]he funding sources for infrastructure are relatively few, and tend to be derived from taxation, user fees or other charges. Financing refers to the financial models that organize how the revenue (or funding) sources are turned into capital" (2015: 3). In other words, financing requires turning sources of funding (for example, water charges) into a mechanism (financial product) for borrowing money for capital investment in the present.

8 Kate Bayliss makes the relatively obvious but important point that framing the provision of basic services (like water) in terms of the 'financial gap' ignores or marginalizes other ways of approaching the problem. It also succeeds in mobilizing governments, non-governmental and private financial institutions to design new ways of accessing finance which generates new financial instruments, techniques and opportunities for financial accumulation.

${ }^{9}$ Kate Bayliss suggests this kind of trajectory when she writes: "Privatization also lays the groundwork for financialization by transforming a public service into a tradeable asset".

${ }^{10}$ In 2014 the National Treasury Management Agency Act was passed. This established the $€ 6.8$ billion Ireland Strategic Investment Fund (ISIF) and gave the NewEra Project a statutory footing. The ISIF and NewERA are complementary strategies to assist the development and implementation of government plans for investment in energy, water and next-generation telecommunications.
}

move towards off-balance sheet service provision has also been emerging in other sectors. Indeed, the reform of the Irish water sector is part of broader program of re-structuring in the infrastructure sector (DPER, 2011). ${ }^{10}$ The rationale is that by restructuring the sector around a series of streamlined, semi-state companies that require relatively small amounts of initial seed investment, these companies will then be able to secure their own sources of revenue from charges and from independent borrowing. This will ensure that expenditure and potential borrowing for these services and their expansion will not count towards the government's deficit or debt figures.

In 2011, the consultancy firm Price Waterhouse Coopers (PWC) released an interim report on the setting up of a new state water utility in Ireland. Their findings were based on the particular challenges of the Irish context as well as the best evidence from international experience (including Scotland, England, Wales, Northern Ireland, Germany, France, Netherlands, South Africa, Australia, and Bulgaria). While the setting up of an off-balance sheet, self-financing water company had already been decided by the Irish government (under pressure from the EU/IMF), PWC was hired to identify the optimal utility model for achieving this goal. The choice was between a Public Utility Model and an Agency Model. In brief, the former describes an independent, self-funding utility responsible for operation, maintenance and investment in all water services infrastructure, customer billing and charging. The latter is a company mainly charged with investment in the sector with local authorities operating as agents of the company, retaining their operational responsibilities and delivering smaller scale investment.

The PWC report begins by reinforcing the financial and infrastructural challenges Ireland faces. It states clearly that the scale of financial investment required will not be met by domestic water charges alone, meaning the utility will have to raise "significant levels of external funding" (PWC 2011). The challenge of raising this external private finance coupled with the need to consolidate water services in order to ensure strategic, risk-based investment and compliance with environmental directives determines their conclusion on the type of utility model required:

Optimal external funding is based on the 'investment grade' of individual companies, which is driven by the size of the organisation, the focus and experience of the management team, the stability and efficiency of back office and frontline operational execution and for regulated entities, the ability to comply efficiently and effectively with economic and environmental regulatory requirements. In addition, since the level of external funding available is normally based on earnings, the extent to which operating costs are reduced through the rationalisation, consolidation and simplification of the delivery model increases the level of borrowings available to the company. Consequently, the ability to optimise the level of external funding is best achieved by a single water company, with authority to centrally manage the delivery of water services in Ireland (2011: 12; my italics).

In 2013, the Irish government issued the Water Services Bill, establishing Irish Water as the new state water utility responsible for the operation, maintenance and improvement of all water services infrastructure, customer billing and charging. Following the advice of the PWC report, all water assets, liabilities and responsibilities were transferred from the 34 local water services authorities to the new independent company. On the 1st January 2014, Irish Water officially took over responsibility for the Irish water network. A twelve-year transition period has been set during which the new utility will operate service level agreements with 
the local authorities until their role in water services are phased out. This decision was made despite a near unanimous response from local authorities, including Dublin City Council, asserting that the removal of responsibility from local authorities would adversely affect local democracy and accountability and potentially results in adverse effects on the quality of the service itself (DCC, 2012; GCC, 2012; CCC, 2012). The submissions from the local authorities during the consultation process called for the Agency Model to be used instead, with Irish Water overseeing the introduction of water charges, metering and the raising of finance.

Since taking over the Irish water network in 2014 the challenge for Irish Water has been to wean itself off government financial support, establish a stable revenue stream from household charges and demonstrate to potential external investors that it is an efficient, low-risk investment opportunity. ${ }^{11}$ As can be expected this process of financial engineering is both uncertain and contested. To begin with, the government and Irish Water must have the utility officially taken off the general balance sheet. To achieve this Irish Water must pass the EuroStat 'market corporation test'. This test is carried out to prove that independent state companies or utilities are operating within European competition regulations. This involves two steps. First, the amount of money raised from user fees or charges must "clearly exceed" payments from Government funding. The second test is even tighter, requiring that the amount collected from domestic and non-domestic charges must be equal to 50 per cent of Irish Water's production costs, and should "clearly exceed" this figure "as soon as possible".

Initial financing from the government to Irish Water came in the form of a $€ 250$ million commercial investment from the newly established Irish Strategic Investment Fund (ISIF). This money has gone towards the initial costs of setting up the new utility, including the costs of consultants hired to advise on the organizational and technological systems required for efficient, compliant, self-financing water utility and the estimated $€ 500$ million required to install a national network of water meters. As well as this capital investment, the government has continued to provide annual subventions of on average $€ 450$ million a year (from 2014 and due to run to the end of 2016) to the new utility for the day-to-day running of water services. This is money that would otherwise have gone to local authorities, and money that is largely drawn from motor tax (Ryan, 2015). The plan had been to raise $€ 300$ million from domestic customers in 2015, and $€ 230$ million from non-domestic customers (Taylor, 2014b). However, significant resistance to the introduction of water charges in 2014 forced the government to reduce and guarantee a fixed level for water charges until the end of 2018 (rendering the water meters and the incentive to conserve redundant), as well as granting $€ 100$ water allowance to every household. ${ }^{12}$ Giving $€ 100$ back to each household will cost around $€ 130$ million next year - twice what was budgeted for originally. The net amount of revenue to be collected through household charges is now just $€ 140$ million, a fairly trivial amount in the overall budget sums. This also assumes that over $90 \%$ of users

\footnotetext{
11 For example, in its recent Water Services Strategic Plan (WSSP), the new utility outlined an ambitious investment plan for the next twenty-five years. The plan commits to spending $€ 600$ million a year on capital investment up to 2030 , not including the additional $€ 500 \mathrm{~m}$ required for installing water meters throughout the country. "In order for Irish Water to be able to raise significant finance at favourable interest rates", the WSSP states in the introduction, "it will be necessary for it to demonstrate that it is an efficient water utility company, operating within a stable regulatory framework, with secure revenue streams." (Irish water, 2015 : xi; my italics).

12 Under the 2014 Water Services Act, between January 2015 until 31 December 2018 the fixed charges for domestic water are set at a maximum charge for a single adult home capped at $€ 160$ and the maximum charge for a multi adult home capped at $€ 260$.
}

will pay their bills. However, since the first bills were issued on the 1st April 2015 a strong campaign of non-payment, and continuing uncertainty as to whether Irish Water will continue into the future, has meant the percentage of people paying their bills has been less than $50 \%$.

In July of this year, Irish Water failed the Eurostat test. As well as pointing to the excessive government control over the new utility, the Eurostat report pointed out that "domestic consumers are to be charged at significantly less than cost" for their water. While the government was quick to claim this was only a "minor setback" and that there were "inaccuracies" in the Eurostat report, it has already passed amendments to the Water Services Act of 2014 designed to ensure water users pay their charges in the future (Pollak, 2015). These include a bill that puts responsibility on landlords to ensure tenants pay their water charges, as well as a Civil Debt Bill that will allow deductions from payments to a social welfare recipient, or the attachment of earnings of employees for debts between $€ 500$ and $€ 4000$.

Publicly asserting that failing the Eurostat test means little in terms of the overall strategy of Irish Water, the utility and government remain confident that households will pay their bills (in the face of threats such as the Civil Debt Bill) and that the goal of accessing capital on financial markets will be possible by 2018-2019. Until then, Irish Water will have to continue securing bilateral loans from commercial banks. To date it has borrowed $€ 1$ billion through such loans. In early 2015, the utility secured its first commercial loan from Ulster Bank (a two-year loan worth $€ 100$ million) (Hennessy, 2013). This loan was secured by a government guarantee meaning that the debt is counted as part of the general exchequer debt (Taylor, 2014a). However, Irish Water is also in the process of negotiating further bilateral loans with international commercial banks that are not likely to be guaranteed by the Irish state (Molloy, 2015). These short-term loans are likely to be temporary financial steps to ensure the utility can pass the Eurostat test until revenue from water charges begins flowing in and longerterm loans can be secured.

While Irish Water currently borrows from commercial banks, the ultimate goal is to be in a situation where it can borrow larger amounts of money for long-term infrastructure projects: in its most recent seven year plan it states that by $2021 € 5$ billion will have been invested with $€ 2$ billion arising from domestic and nondomestic charges and the remaining $€ 3$ billion coming from capital markets. While it has not stipulated what kind of financial arrangements this will involve it is likely to involve the issuing of bonds that are secured against future revenues from water charges. ${ }^{13}$ These bonds are different to commercial loans in that they are financial products or assets that can then be traded on secondary markets. Infrastructure bonds have become more popular following the GFC because they promise low-risk, high-yield, inflation-proof investments to long-term investors, such as Pension Funds (Courtois, 2013; Della Croce and Yermo, 2013; Drummer, 2011). Bearing this in mind, it is important to consider how the goal of establishing an independent self-financing water utility has shaped a broader set of decisions taken over the past four or five years regarding the management of the new utility.

\subsection{Improving performance: the modernization of the Irish Water system}

When setting up Irish Water in 2012, the government took the

\footnotetext{
13 Other Irish semi-state utilities, including Bord Gais Eireann, a management partner of Irish Water, have issued five-year bonds in the recent past as the practice and market for infrastructure bonds has expanded.
} 
decision to partner the new utility with an existing semi-state company, Bord Gais. ${ }^{14}$ While Irish Water will operate as a separate, independent company from Bord Gais, it was considered important that there be a 'Management Partner' with expertise in the management of a major national utility - in this case the gas and energy sector. As with the decision to establish a single, centralized utility for water services, the rationale behind choosing Bord Gais as a management partner was to alleviate risk and help Irish Water avail of key expertise in raising finance, ${ }^{15}$ operating as a utility in a regulated environment, and adopting effective management practices in the areas of customer relations, network management and metering and utility operation systems (Irish Water 2014).

When Bord Gais was given the contract to establish Irish Water they received $€ 180$ million from the government's National Reserve Pension Fund (now Irish Strategic Investment Fund) to establish the new utility. $€ 100$ million was spent on new management systems and $€ 85$ million on fees for external consultancy services. ${ }^{16}$ In 2014, the Public Accounts Committee ${ }^{17}$ was given a rare opportunity to question Bord Gais (since Ervia) on these costs. The representative for Ervia defended them on the basis that they were needed to bring the Irish water system into the twenty-first century. "Our ambitions as a company are to build out a high performing modern utility", he said, "the hallmarks of which are a focus on cost savings and efficient operations, quality customer service, and delivery of capital investments to time, to quality and to budget" (Irish Water 2014). In order to achieve these goals, Information Management Systems are required that will be supported by state of the art ICT systems. These developments are considered an essential ingredient in the overall vision of Irish Water: to become a self-financing, compliant and resource-efficient water utility. There are two main areas where these new information management systems are being implemented.

The first area is the water network itself. This responds to the perceived inadequacy of the previous, fragmented approach to water management carried out by local authorities "without consistency of policy, uniformity of standards or risk metrics" (Irish Water 2014). In part this is a response to demands from the European Commission for member states to more appropriately value natural resources, such as water, and the various services it performs within the economy and ecosystems (The European Environment 2015). If we take the European objective of having 'good status' in all watercourses and supplies by 2015 (extended now to 2020), we can begin to see that such benign-sounding requirements do not just put financial pressure on states to comply but rather demand new ways of assessing and managing the

\footnotetext{
14 Bord Gais has now changed its name to Ervia after selling part of its operations to the private company, UK based energy company Centrica.

15 For example, Bord Gais Eireann (BGE, a subsidiary of Ervia) recently managed to raise finance that was guaranteed through a deal with a Danish export credit agency. The money was to buy equipment for several new wind farms from Danish companies. BGE also has experience in issuing infrastructure bonds (Corcoran, 2013).

16 The largest recipient was IBM ( $€ 44.8 \mathrm{~m}$ ), who designed, delivered and integrated all roles, business processes, systems and data required to enable Customer Capability, Work and Asset Management capability and Support services; Accenture ( $€ 17.2 \mathrm{~m}$ ) who provided Programme Management across the Business Capability areas of Irish Water; Ernst \& Young $(€ 4.6 \mathrm{~m})$ who provided project design for each project in the areas of Finance, Governance and Regulation, facilities and Custome engagement; and KPMG ( $€ 2.2 \mathrm{~m}$ ) who provided Quality Assurance Services on the operation and deliverables on the programme to Senior Executives and the Board of Irish Water (Submission Irish Water 2014).

17 The Public Accounts Committee is the public spending watchdog. It is designed to ensure that there is accountability and transparency in the way Government agencies allocate, spend and manage their finances and in guaranteeing that the taxpayer receives value for money.
}

performance of water resources, including rivers, lakes, groundwater, and coastal waters. At the same time an asset-based approach to water management promises significant cost-savings and efficiencies. Irish Water draws on international benchmarks in this area that suggest efficiencies of up to $40 \%$ are achievable in capital investment if "the right choices can be made and delivered efficiently". Efficient in this sense does not just mean reducing labor costs but reducing energy use, water loss and water consumption through the adoption of new technological and managerial innovations. In order to bring about such improvements it is critical that there be centralized strategic planning based on "accurate asset performance data and full control of all investment decisions, both capital and operational" (Irish Water 2014). Irish Water have thus invested heavily in the creation of an asset management system that will be capable of collecting and maintaining information on the condition and performance of all assets in the water network - including treatment plants, leakages, pressure in the pipes and household usage. This system will produce a central repository for a huge range of data on assets that in turn will become "the driver for risk based decision making for the capital investment plan". Investments in the water network will be optimized and, crucially, the utility will be able to prove to customers, regulators and potential investors "that every euro we spend on the asset base delivers a maximum return". Irish Water is thus seeking to "embed the Asset Management culture across all of [their] activities in order to optimize the performance of assets, through appropriate operation processes, maintenance and replacement regimes and performance monitoring".

As well as having to account for the $€ 11$ billion worth of material assets, Irish Water also needs to ensure a secure stream of revenue from household charges. All government funding to the new utility is expected to come to an end by 2020 , meaning that the financing of operational and capital costs will depend on domestic and commercial charges and the ability to borrow from institutional investors. Irish Water has already embarked on one of the most ambitious water metering programs of any water utility worldwide. While this follows the user-pays principle and is anticipated to reduce water demand through household management, the meters also provide detailed information on customer demand (Torrance, 2008). The metering project is costing Irish Water an estimated $€ 500$ million and has been met with strong resistance from communities around Ireland. One of the consequences, as stated earlier, has been a decision to charge a flat, fixed rate until the end of 2018. The government and Irish Water continue to defend the metering scheme however as a long-term investment in line with modern water utilities around the world.

These management information systems are expected to ensure cost savings of a minimum of $€ 2$ billion for the exchequer by 2021 . By then the utility is also expected to be self-financing on the basis of water charges and external funding. Borrowing capacity for the utility will increase as the utility is able to prove predictable revenues and efficient, cost-effective asset management: the Price Waterhouse Cooper report estimated the debt capacity of the business could rise from $€ 606$ million in 2015 to potentially $€ 2.9$ billion by 2030 partly on the basis of such efficiency measures. This financial investment will in turn allow Irish Water to better address the most pressing water quality problems and comply with European directives. In a recent interview Michael McNicholas, CEO of Irish Water, reinforced this intimate relationship between access to flows of finance and the modernization of the water system when he said: "[a]s we drive efficiencies we will have greater capacities to go to the borrowing markets" (Rte 2015). The new asset management and customer information systems are understood to be necessary and crucial components of this relationship, enabling continuous monitoring and improvement within an increasingly 
demanding and competitive regulatory and financial context.

There has been a considerable body of literature examining the expansion of neoliberal auditing technologies and techniques in both the private and public sector over the past three decades (Burchell, 1996; Dardot and Laval, 2013; De Angelis and Harvie, 2009; Strathern, 2000). This work traces the development of instruments of assessment and evaluation to all manner of social and environmental activity (work, education, health care). The reasoning behind this culture of evaluation is that disparate subjects, assets and activities can be compared and assessed over time inciting innovation and improved performance. This has become most obvious in the work place where individual activity is subject to forms of measurement and evaluation in order to improve performance and productivity. These kinds of internal, work management practices have now migrated to the public sector and are identified in the literature on New Public Management and corporatization (McDonald, 2014). ${ }^{18}$ Interestingly, similar forms of neoliberal governance are now being applied in the fields of environmental conservation and ecosystems services: by measuring the value of diverse, situated non-human actors and relationships these 'externalities' are not only accounted for but also rendered commensurate through a common apparatus of measuring techniques and technologies (Büscher et al. 2012; Brockington, 2011; Robertson, 2006; Sullivan, 2013). As Sian Sullivan writes, “mapping, measuring and monetisation techniques are thus deployed to produce comprehensive ecosystem services catalogues, applicable from local to global scales" (Sullivan, 2013: 205). This work points to a transformation in what 'nature' becomes within ecological modernization: no longer a raw material input or 'externality' metabolized within the production process, but a performing asset that can be measured, evaluated, compared and potentially traded with other assets within highly technical networks.

While this literature focuses on the agendas around Natural Capital Accounting and the techno-scientific work required to assign measurable, economic values to situated and complex ecologies (rivers, soil, forests), it is productive to extend this analysis to the transformations currently underway in the makingvisible of core infrastructures like water. Just as payments for ecosystems services (PES), for example, attempt to measure and thus abstract distinct parts and processes of non-human nature, so too are instruments of measurement emerging that (supposedly) represent the financial and ecological value of entire infrastructures. The growing imperative for water utilities (private or public) to access finance directly through global financial markets and to modernize aging infrastructures to meet the exacting and highly technical standards of environmental regulations is driving the need for these new systems of measurement and evaluation. This has not only opened new areas for technological innovation but also for profit as the process of translating the previously 'invisible', inefficient water network into a fully accounted-for and high-performing infrastructure asset gets underway. ${ }^{19}$ In the case of Irish Water this includes, for example, measuring and demonstrating the quality of the water resources, the pressure in the pipes, the energy consumption of the treatment plants and, of course, the future revenues to be generated from water charges.

\footnotetext{
${ }^{18}$ Irish Water is no different in this regard, having established a pay model in which a portion of individual salaries is deliberately set at risk - if targets are not hit, the employee loses out on that segment of their salary.

19 This is evident in the recent, dramatic shift in the business profile of Veolia, one of the best-known global private water companies. In a recent report, the company signaled both the growing financial restrictions on governments and the increasingly demanding ecological requirements in parts of the Global North as proof that there would be growing demand for environmental services and 'value-added solutions' to water, waste and energy management.
}

Irish Water claims that this information and the asset-based systems of management underlying it are needed to rationalize and modernize the water system. But the informational value that is extracted from the water system is not neutral or universal. There is always a disparity between the measurement of an activity and the existence of other qualities and values associated with that activity that are excluded by the instruments of measurement (De Angelis and Harvie, 2009). The reality is that this move is driven by the need to comply with highly technical European environmental standards and, perhaps more significantly, the demands of global financial investors (Inderst, 2009; Turner, 2014). It is this imperative - to translate the Irish water system into the legible, economic terms of bio-financial value - that characterizes the process of biofinancialization (Lilley and Papadopoulos 2014).

\section{Conclusion}

In their recent article, 'Banking Spatially on the Future: Capital Switching, Infrastructure, and the Ecological Fix' (2015), Noel Castree and Brett Christophers make an important analytic connection between the climate crisis and the financial crisis. They focus their attention on the unprecedented and capital-intensive infrastructure projects (from housing to road to energy and water provision) that will be required as the effects of climate change intensify. They also see how such investments can provide a positive and socially progressive response to the current financial (and more broadly, economic) crisis by drawing some of the vast reserves of financial capital away from speculative, short-term investments into more productive, sustainable and long-term investments that benefit society at large. This argument fits within a more general call for a 'green' New Deal, and more specifically a body of literature that has been examining ongoing changes in the governance and financing of core infrastructure that move beyond the impasse of the publicprivate binary (Allen and Pryke, 2013; O'Neill, 2010, 2015). For Castree and Christophers, the objective of national governments and policy-makers should be to find ways of attracting financial investment into infrastructure, thereby linking the flows of financial capital with the flows of vital resources necessary for social and ecological reproduction. In this paper, I have sought to show that something like this process is happening in the context of Irish Water: in an effort to harness external sources of finance to modernize the Irish water infrastructure new relations are emerging between financial markets, the state, the Irish population and the water network itself. This unstable arrangement does not, however, tend towards more progressive hydro-social futures. Rather it represents new advances in the neoliberalization of vital services. I want to conclude by emphasizing three points in this regard.

First, rather than emphasizing geographic and historical variations in how neoliberalism manifests itself, I want to point to what remains consistent to neoliberalism in all its protean forms: the guiding logic of competition as the basis for good government. In response to financial and environmental challenges, the Irish government has established Irish Water as an instrument for demonstrating and thus comparing both the financial and environmental performance of the water infrastructure as a whole; it is this logic of evaluation and comparison that is assumed to drive efficiencies. Irish Water represents important and novel steps in the process of bio-financial engineering through which more and more aspects of the hydro-social cycle become measurable and thus legible within globalized financial and regulatory domains. It is also important to note that what is becoming valuable here is not the use-value of Ireland's water resources or existing infrastructure but their future value as performing assets. In this way, an entire water infrastructure is translated into "a speculative opportunity like any other 
in a market hungry for critical events" (Cooper, 2010:175). One clear consequence of this is the central role that such technologies and techniques of measurement will play in the future (and already do) as they mediate and represent the value of the water network and the comparative performances of the utility and of individual households. While it is too early to tell what the consequences of this will be it is clear that the overlaying of new instruments and systems of valuation onto social and ecological activities and processes are not external or secondary to the activities themselves (Pellizzoni, 2011). The most obvious example is the system of water metering. Defended by the government, Irish Water and many environmental groups as a way of incentivizing water conservation, this type of auditing technology reflects just one moment in the more general extension of value-measurement that will change how people relate to and value water. While individualizing responsibility for water conservation provokes justified resistance, the wider issue is that once value is imbued in the appearance of an activity rather than the activity itself a 'short-circuiting' can take place, and the disparity between complex socio-material realities and a set of representations circulating as environmental data within new (largely unaccountable) techno-managerial systems will become more pronounced.

Second, the case of Irish Water departs in important ways from an understanding of neoliberalism that emphasizes the 'retreat' of the state and the 'advance' of the market. The main protagonist in the process of bio-financialization has been the Irish state - passing a Water Services Act that consolidates all water services and responsibilities into one, centralized utility; providing the necessary finance to establish the new utility and a state guarantee of up to $€ 2$ billion for borrowings by Irish Water; potentially enacting legislation that will allow unpaid charges to be subtracted from wages and social payments. The scale of reform required to turn a water utility such as Irish Water into an 'investment grade' asset requires significant and ongoing intervention. Once we recognize this we can begin to decipher the key role of the state in enabling the growing financialization of infrastructure - the financial enclosure of public goods, the shift from public utility to financial product (O'Neill, 2015). In this sense, there is a clear need to be critical of the perceived 'public' re-orientation of water services in a context where the state itself becomes the central agent in effectively securing new revenue streams/financial assets for private financial investors (O'Brien and Pike, 2015).

Finally, the establishment of Irish Water has provoked by far the largest and most significant mobilization of people since the economic crisis of 2008 and the austerity policies implemented after 2010. The main target of opposition has been the introduction of water charges. These are rightly seen as regressive and an unfair burden on many people after five years of austerity. Grassroots opposition to the installation of water meters and widespread criticism of the lack of transparency and accountability displayed by Irish Water also reflect a popular understanding that public management of water services is about more than just who pays for it. In a context where the financial viability of the new utility relies on the disciplining of water users as reliable new sources of revenue and the consolidation of the water network within one, highly technical entity, it is clear that ongoing forms of resistance will provide an effective obstacle to the re-organization of the Irish water system. A likely consequence will be an inability to access external sources of finance for the upgrading of the water system

\footnotetext{
20 The Right2Water Campaign is a public campaign by activists, citizens, community groups, political parties/individuals and trade unionists who are calling for the Government to recognise and legislate for access to water as a human right and to stop the introduction of water charges.
}

through the issuing of bonds - ongoing uncertainty around the future of the new semi-state company is a red flag for potential investors. Currently, organizers of the Right2Water Campaign ${ }^{20}$ remain focused on reversing the water charges, abolishing Irish Water and returning to the previous model of financing water services through general taxation. However, this position does not appear to grasp the globalized and financialized character of the economy, nor does it have much to say about how a twenty first century infrastructure might actually be organized in a way that reflects new environmental demands and technical possibilities. As Castree and Christophers' proposal outlines, it is necessary to engage with the possibilities and potential for new ways of financing and governing vital infrastructures that neither rely on a nostalgic return to the past, nor the opaque, uneven financial arrangements and highly technical alternative that appears to be unfolding in the case of Irish Water.

\section{Acknowledgements}

I would like to thank Mareike Beck and Andrea Brock for organizing the 'Financialization of Nature' Conference in March 2015 at the STEPS Centre in the University of Sussex, UK, where this paper was first presented. I would also like to thank the anonymous reviewers for their useful feedback. This research was funded by an Irish Research Council Postdoctoral Fellowship.

\section{References}

Allen, John, Pryke, Michael, 2013. Financialising household water: Thames water, MEIF, and 'ring-Fenced' politics. Camb. J. Regions, Econ. Soc. 6 (3), 419-439.

Ashton, Philip, Doussard, Marc, Weber, Rachel, 2012. The financial engineering of infrastructure privatization: what are public assets Worth to private investors? J. Am. Plan. Assoc. 78 (3), 300-312.

Bakker, Karen J., 2003a. A political ecology of water privatization. Stud. Political Econ. 70.

Bakker, Karen J., 2003b. Archipelagos and networks: urbanization and water privatization in the south. Geogr. J. 169 (4), 328-341.

Bakker, Karen J., 2005. Neoliberalizing nature? market Environmentalism in water Supply in England and Wales. Ann. Assoc. Am. Geogr. 95 (3), 542-565.

Bakker, Karen J., 2013. Constructing 'public'water: the world bank, urban water Supply, and the Biopolitics of development. Environ. Plan. D Soc. Space 31 (2), 280-300.

Beck, Ulrich, 1994. Reflexive Modernization: Politics, Tradition and Aesthetics in the Modern Social Order. Stanford University Press.

Brockington, Dan, 2011. Ecosystem services and fictitious commodities. Environ. Conserv. 38 (4), 367-369.

Budds, Jessica, McGranahan, Gordon, 2003. Are the debates on water privatization Missing the Point? experiences from africa, Asia and Latin America. Environ. Urban. 15 (2), 87-114.

Burchell, Gary, 1996. Liberal government and techniques of the self. In: Barry, Andrew, Osborne, Thomas, Rose, Nikolas (Eds.), Foucault and Political Reason. UCL Press, London, pp. 19-36.

Büscher, Bram, Sullivan, Sian, Neves, Katja, Igoe, Jim, Brockington, Dan, 2012. Towards a synthesized critique of neoliberal biodiversity conservation. Capital. Nat. Social. 23 (2), 4-30.

Camdessus, Michael, Winpenny, James, 2003. Financing Water for All: Report of the World Panel on Financing Water Infrastructure. Global Water Partnership, World Water Council, World Water Forum.

Castree, Noel, Christophers, Brett, 2015. Banking spatially on the future: capital switching, infrastructure, and the ecological fix. Ann. Assoc. Am. Geogr. 105 (2), $1-9$.

CCC., 2012a. Response to Consultation on the Establishment of a Public Water Utility.

CEC., 2012b. A Blueprint to Safeguard Europe's Water Resources. COM. final. European Commission, p. 673.

Christopherson, Susan, Martin, Ron, Pollard, Jane, 2013. Financialisation: roots and repercussions. Camb. J. Regions Econ. Soc. 6 (3), 351-357.

Clark, Gordon L., Monk, Ashby HB., Orr, Ryan, Scott, William, 2012. The New Era of infrastructure investing. Pensions An Int. J. 17 (2), 103-111.

Cooper, Melinda, 2008. Life as Surplus: Biotechnology and Capitalism in the Neoliberal Era. University of Washington Press.

Cooper, Melinda, 2010. Turbulent Worlds. Financial Markets and environmental crisis. Theory Cult. Soc. 27 (2-3), 167-190.

Corcoran, Sorcha, 2013. Landmark Bord Gais Eireann deal shows funding options are out there. Bus. Leadersh. November 7.

Courtois, Yves, 2013. Infrastructure: an emerging global asset class. Inflat. Linked 
Long Durat. Charact. Appeal Pension Funds. CFA Inst. Mag. 24 (6), 16-19.

Dardot, Pierre, Laval, Christian, 2013. The New Way of the World: on Neoliberal Society. Verso.

DCC., 2012. Consultation on Reform of the Water Sector in Ireland (Submission by the Executive of Dublin City Council.)

De Angelis, Massimo, Harvie, David, 2009. Cognitive capitalism' and the rat-race: How Capital Measures Immaterial Labour in British Universities. Hist. Mater. 17 (3), 3-30.

Della Croce, Raffaele, Yermo, Juan, 2013. Institutional Investors and Infrastructure Financing. (OECD Working Papers on Finance, Insurance and Private Pensions).

Doris, Yvonne, Ni Eidhin, Cliona, Hayes, Nigel, Wall, Brendan, Page, Darragh, Devaney, Derval, Loughnane, Aoife, Flynn, David, O'Leary, Gerard, 2013. Drinking Water Report 2013. Environmental Protection Agency.

DPER., 2011. Infrastructure and Capital Investment 2012-16: Medium Term Exchequer Framework. Department of Public Expenditure and Reform.

Drummer, Randyl, 2011. City of Austin Uses Infrastructure Bond Financing to Move Projects Forward. CoStar. December 14. http://www.costar.com/News/Article/ City-of-Austin-Uses-Infrastructure-Bond-Financing-to-Move-Projects-Forward/ 134343.

EC Harris Build Asset Consultancy, 2013. Global Infrastructure Investment Index: Move from Risk to Reward.

Epstein, Gerald, 2005. In: Epstein, Gerald (Ed.), Introduction." Financialization and the world economy. Edward Elgar Publishing, Cheltenham.

European Environment Agency, 2015. The European Environment. State and Outlook 2015. Synthesis Report." 2015. European Environment Agency, Luxembourg.

Fine, Ben, 2009. Financialization and Social Policy. In: Presented at the NRISD Conference on the "Social and Political Dimensions of the Global Crisis: Implications for Developing Countries," Geneva. http://eprints.soas.ac.uk/7984/1/ unrisdsocpol.pdf.

GCC, 2012. Submission on Behalf of Galway County Council with Regard to Reform of the Water Sector in Ireland - Public Consultation.

Hall, David, 2009. Economic Crisis and Public Services: a Crisis for Public-private Partnerships (PPPs)? Public Services International Research Unit.

Hall, David, Lobina, Emanuele, 2010. The Past, Present and Future of Finance for Investment in Water Systems. In: IRC International Water and Sanitation Centre, IRC Symposium. http://www.right2water.eu/sites/water/files/2010-11W-finance.pdf.

Helm, Dieter, Tindall, Tom, 2009. The Evolution of Infrastructure and Utility Ownership and Its Implications. Oxf. Rev. Econ. Policy 25 (3), 411-434.

Hennessy, Michelle, 2013. $€ 200 \mathrm{~m}$ EIB Loan to Finance 23 Irish Water Investment Projects. J. ie. January 24. http://businessetc.thejournal.ie/eib-loan-waterprojects-767486-Jan2013/.

Pigeon, Martin, McDonald, David A., Hoedeman, Olivier, Kishimoto, Satoko (Eds.) 2012. Remunicipalisation: Putting Water Back into Public Hands. Transnational Institute, Amsterdam.

Inderst, Georg, 2009. Pension Fund Investment in Infrastructure. OECD Working Papers on Insurance and Private Pensions 32.

Kaika, Maria, 2003. The water framework directive: a new directive for a changing social, political and economic European framework. Eur. Plan. Stud. 11 (3), 299-316.

Lapavitsas, Costas, 2009. Financialised Capitalism: Crisis and Financial Expropriation. Hist. Mater. 17 (2), 114-148.

Lilley, Simon, Papadopoulos, Dimitris, 2014. Material returns: cultures of valuation. Biofinancialisation Aut. Polit. Sociol, 48 (5), 972-988.

Loftus, Alex, Hug, March. 2015. Financializing nature? Geoforum 60, 172-175.

March, Hug, Purcell, Thomas, 2014. The muddy waters of financialisation and new accumulation strategies in the Global Water Industry: the case of AGBAR. Geoforum 53, 11-20.

March, Hug, Saurí, David, 2013. The unintended consequences of ecological modernization: debt-induced reconfiguration of the water cycle in Barcelona. Environ. Plan. A 45 (9), 2064-2083.

McDonald, David A., 2014. Rethinking Corporatization and Public Services in the Global South. Zed Books, London.

Mol, Arthur P.J., Spaargaren, Gert, 2000. Ecological modernisation theory in debate: a review. Environ. Polit. 9, 17-49.

Molloy, Thomas, 2015. Irish Water to Borrow $€ 550 \mathrm{~m}$ Just Weeks after Ulster Bank Deal. The Irish Independent. February 8. http://www.independent.ie/business/ irish/irish-water-to-borrow-550m-just-weeks-after-ulster-bank-deal30972705.html,

OECD., 2010. Innovating Financing Mechanisms for the Water Sector. http://www. oecd-ilibrary.org/environment/innovative-financing-mechanisms-for-thewater-sector 9789264083660-en.

OECD., 2014. Private Financing and Governmental Support to Promote Long-term Investments in Infrastructure. Organisation for Economic Cooperation and Development, Paris.
O'Brien, Peter, Pike, Andy, 2015. The Financialisation and Governance of Infrastructure. IBUILD Working Paper No. 8.

O'Neill, Philip, 2010. Infrastructure Financing and Operation in the Contemporary City. Geogr. Res. 48 (1), 3-12.

O'Neill, Philip, 2015. Infrastructure's Stubborn Spatiality and Its Maturing Financialisation. Soc. Sci. Res. Netw.

Pellizzoni, Luigi, 2011. Governing through Disorder: Neoliberal Environmental Governance and Social Theory. Glob. Environ. Change 21, 795-803.

Petersen, Thomas, Klauer, Bernd, Manstetten, Reiner, 2009. The Environment as Challenge for Governmental responsibility-The Case of the European Water Framework Directive. Ecol. Econ. 68 (7), 2058-2065.

Pollak, Sorcha, 2015. Eurostat Irish Water Ruling a 'minor Setback', Says Varadkar. July 31. Irish Times. http://www.irishtimes.com/news/politics/eurostat-irishwater-ruling-a-minor-setback-says-varadkar-1.2303275.

Price WaterHouse Coopers, 2011. Irish Water: Phase 1 Report.

Ramesh, M. Araral, Eduardo, 2010. Introduction: Reasserting the Role of the State in Public Services. In: Ramesh, M., Araral, Eduardo, Wu, Xun (Eds.), Reasserting the Public in Public Services: New Public Management Reforms. Routledge, pp. $1-16$.

Robertson, Morgan, 2006. The Nature That Capital Can See: Science, State, and Market in the Commodification of Ecosystem Services. Environ. Plan. D Soc. Space 24, 367-387.

Ryan, Orla, 2015. Two Thirds of the Money Diverted to Irish Water Came from Your Motor Tax. J. ie. February 5. http://www.thejournal.ie/how-much-will-it-costto-set-up-irish-water-1921250-Feb2015/.

Schwartz, Klaas, 2008. The New Public Management: The Future for Reforms in the African Water Supply and Sanitation Sector? Util. Policy 16 (1), 49-58.

Smith, Laila, 2004. The Murky Waters of the Second Wave of Neoliberalism: Corporatization as a Service Delivery Model in Cape Town. Geoforum 35 (3), 375-393.

Smith, Laila, 2006. Neither Public Nor Private: Unpacking the Johannesburg Water Corporatization Model. UNRISD.

Strathern, Marilyn (Ed.), 2000. Audit Cultures: Anthropological Studies in Accountability, Ethics and the Academy. Routledge, London \& New York.

Sullivan, Sian, 2013. Banking Nature? The Spectacular Financialisation of Environmental Conservation. Antipode 45 (1), 198-217.

Swyngedouw, Erik, 1997. Power, nature, and the City. The conquest of water and the political ecology of urbanization in Guayaquil, Ecuador: 1880-1990. Environ. Plan. A 29, 311-332.

Swyngedouw, Erik, 2006. Power, Water and Money: Exploring the Nexus. Human Development Report Occasional Paper 2006/14 14. United Nations Development Program.

Taylor, Cliff, 2014a. State Underwrites New $€ 100 \mathrm{~m}$ Borrowing by Irish Water November 13. Irish Times. http://www.irishtimes.com/news/ireland/irishnews/state-underwrites-new-100m-borrowing-by-irish-water-1.1998493.

Taylor, Cliff, 2014b. Irish Water Will Still Need Drip-drip of State Funding. November 19. The Irish Times. http://www.irishtimes.com/news/ireland/irish-news/irishwater-will-still-need-drip-drip-of-state-funding-1.2007482.

Thiel, Andreas, 2009. Europeanisation and the rescaling of water services: agency and state spatial strategies in the Algarve, Portugal. Water Altern. 2 (2) 225-244.

Thompson, Christopher, 2013. Infrastructure Bonds Grab Investor Attention December 2. Financial Times. http://www.ft.com/intl/cms/s/0/eff0aac8-590911e3-9798-00144feabdc0.html\#axzz3age67FZT.

Torrance, Morag, 2008. Forging Glocal Governance? Urban infrastructures as networked financial products. Int. J. Urban Regional Res. 32 (1), 1-21.

Turner, David, 2014. Why Investors Are Returning to Infrastructure Bonds. Investor January 8. http://www.institutionalinvestor.com/article/3294673/assetmanagement-fixed-income/why-investors-are-returning-to-infrastructurebonds.html\#.VQMcvigdVUQ.

Van Rooyen, C., Hall, David, 2007. Public Is as Private Does: The Con- Fused Case of Rand Water in South Africa. MSP Occasional Paper. Municipal Services Project, Cape Town.

Warner, Rosalind, 2010. Ecological Modernisation Theory: towards a critical ecopolitics of change? Environ. Polit. 19, 538-556.

Water, Irish, 2014. Submission to the Joint Oireachtas Committee on the Environment, Culture and the Gaeltacht - Irish Water Programme and Irish Water. www.oireachtas.ie/.../committees/ environmenttransportcultureandthegaeltacht/JOC-Submission docx.

Water, Irish, 2015. Water Services Strategic Plan (WSSP). A Plan for the Future of Water Services. http://www.water.ie/docs/Draft-WSSP.pdf.

Whittaker, Alice, 2012. The Challenge for Irish Water: Setting the Price of Water and Recovering the Costs. August 17. Public Affairs Ireland. http://www. publicaffairsireland.com/news/1147-the-challenge-for-irish-water-setting-theprice-of-water-and-recovering-the-costs. 